\title{
CACNA1A Mutation in a EA-2 Patient Responsive to Acetazolamide and Valproic Acid
}

\author{
Kylie A. Scoggan, Joseph H. Friedman, Dennis E. Bulman
}

\begin{abstract}
Background: Episodic ataxia type-2 (EA-2) is an autosomal dominant neurological disorder that has been shown to result from mutations in the CACNA1A gene encoding the P/Q-type calcium channel. Affected individuals experience episodes of cerebellar ataxia usually associated with migraine symptoms, interictal nystagmus, mild residual and in some cases a progressive cerebellar incoordination and respond to acetazolamide treatment. We identified a patient with a positive family history for episodic ataxia, who was originally diagnosed with epilepsy and treated with valproic acid. Subsequent examination revealed that the symptoms were consistent with a diagnosis of EA-2. The patient responded positively to a combination of acetazolamide and valproic acid. Molecular genetic analysis of the CACNAIA gene was performed in order to confirm a diagnosis of EA-2. Methods: The CACNA1A gene was evaluated for mutations using single strand conformational polymorphism analysis and direct DNA sequencing. Allele specific oligo hybridization was used to confirm that the mutation was segregating with only affected family members and was not present in the control group. Results: In this study we identified a new missense mutation in exon 12 of the CACNA1A gene from a patient with EA2 whose symptoms could be controlled with a combination of acetazolamide and valproic acid. This $\mathrm{G}$ to A transition changes a highly conserved glutamic acid residue to a lysine residue in domain II S2 of the P/Q-type calcium channel $\alpha_{1 \mathrm{~A}}$ subunit. Conclusions: The use of valproic acid in treating patients with EA-2 is not well documented. Here we describe a patient with a novel mutation in the CACNA1A gene who responded positively to a combination of acetazolamide and valproic acid.
\end{abstract}

RÉSUMÉ: Mutation du gène CACNA1A chez un patient porteur d'une AE-2 qui répond à l'acétazolamide et à l'acide valproïque. Contexte: L'ataxie épisodique de type 2 (AE-2) est une maladie neurologique de transmission autosomique dominante qui est due à des mutations du gène CACNA1A codant le canal calcique de type $\mathrm{P} / \mathrm{Q}$. Les individus atteints présentent des épisodes d'ataxie cérébelleuse habituellement associés à des symptômes migraineux, un nystagmus intercritique, une légère incoordination cérébelleuse résiduelle qui est progressive chez certains patients et répond au traitement par l'acétazolamide. Nous avons identifié un patient ayant une histoire familiale d'ataxie épisodique, chez qui un diagnostic d'épilepsie avait été posé et qui avait été traité par l'acide valprö̈que. Un nouvel examen du patient a permis de déterminer que ses symptômes étaient suggestifs d'une AE-2. Le patient a bien répondu à une association médicamenteuse, soit l'acétazolamide administré avec l'acide valproïque. L'analyse du gène CACNA1A a été effectuée pour confirmer le diagnostic d'AE-2. Méthodes: Des mutations du gène CACNA1A ont été recherchées par la technique de détection des polymorphismes de conformation monocaténaires (single-strand conformation polymorphism - SSCP) et par séquençage direct de l'ADN. L'hybridation d'un oligo allèle spécifique a confirmé que la mutation ségrégait seulement chez les membres atteints de la famille et n'était pas présente chez le groupe témoin. Résultats: Nous avons identifié une nouvelle mutation faux-sens dans l'exon 12 du gène CACNA1A de ce patient atteint d'AE2 dont les symptômes étaient contrôlés par une association médicamenteuse, soit l'acétazolamide et l'acide valproïque. La substitution d'un A à un G change un acide glutamique hautement conservé en une lysine dans le domaine II S2 de la sous-unité a1A du canal calcique de type P/Q. Conclusions: Il existe peu de données sur l'utilisation de l'acide valproïque pour traiter les patients atteints d'AE-2. Nous décrivons un patient porteur d'une nouvelle mutation du gène CACNA1A qui a bien répondu à une association médicamenteuse, l'acétazolamide et l'acide valproïque.

Can. J. Neurol. Sci. 2006; 33: 68-72

Episodic ataxia type-2 (EA-2) (OMIM 108500) is inherited as an autosomal dominant neurological disorder. Affected individuals experience discrete episodes of cerebellar ataxia usually associated with migraine symptoms, interictal nystagmus, as well as residual mild and in some cases a progressive cerebellar incoordination. Attacks usually begin in childhood or adolescence, last a few hours, may be precipitated by stress, exercise or fatigue, and respond to acetazolamide..$^{1-3}$ One of three allelic disorders, EA-2, is due mainly to specific classes of mutations in the CACNA1A gene. ${ }^{4}$ Generally, missense mutations in CACNA1A are responsible for familial hemiplegic migraine, while a trinucleotide repeat expansion causes spinocerebellar ataxia type 6 , and premature termination of translation mutations result in EA-2. In a few instances, missense mutations have been identified to cause EA-2 $2^{5-9}$ and a repeat expansion mutation was responsible for a case of progressive cerebellar ataxia. ${ }^{10,11}$

The CACNA1A gene codes for the $\alpha_{1 \mathrm{~A}}$ subunit of the P/Q-

From the Ottawa Health Research Institute (KAS, DEB); Nutrition Research Division, Health Canada (KAS); Division of Neurology, Brown University (JHF); Division of Neurology, University of Ottawa (DEB), Ottawa, ON, Canada, NeuroHealth Parkinson's Disease and Movement Disorders Center 227 (JHF), Warwich, RI, USA. Received April 28, 2005. ACCEPTEd IN FinAl FORM SEPTEMBER 24, 2005. Reprint requests to: Dennis E. Bulman, Ottawa Health Research Institute, 501 Smyth Road, Ottawa, Ontario, K1H 8L6, Canada. 
type calcium channel, which is the pore forming unit of the channel. ${ }^{12,13}$ The $\alpha_{1 \mathrm{~A}}$ subunit is involved in controlling neurotransmitter release ${ }^{14}$ and is expressed throughout the brain with abundant expression in the cerebellum. ${ }^{15-17}$ This highvoltage-activated calcium channel consists of five subunits, $\alpha_{1 \mathrm{~A}}$, $\beta_{4}, \alpha_{2}, \delta$, and $\gamma$. The $\alpha_{1 \mathrm{~A}}$ subunit is subdivided into four homologous domains (DI-DIV), each of which contains six transmembrane regions (S1-S6). ${ }^{14}$ The fourth transmembrane domain functions as the voltage sensor while the four loops between transmembrane domains S5-S6 compose the pore forming unit. Thus, the $\alpha_{1 \mathrm{~A}}$ subunit of the P/Q-type calcium channel is responsible for directing channel activity, while the other subunits appear to act as auxiliary regulators of the channel. ${ }^{14-18}$

In mice, recessive mutations in the CACNA1A gene, result in cerebellar ataxia and symptoms similar to human absence epilepsy, ${ }^{19}$ a condition commonly treated with valproic acid. Mutations in the P/Q-type calcium channel auxiliary $\beta$ subunit and $\gamma$ subunit have also been demonstrated to result in absence seizures in mice. ${ }^{20-21}$ A nonsense mutation in the $\beta_{4}$ subunit caused juvenile myoclonic epilepsy in a woman who experienced sporadic typical absence seizures and repetitive bilateral myoclonic jerks in the shoulders and arms after awakening without loss of consciousness. ${ }^{22} \mathrm{~A}$ missense mutation caused generalized epilepsy with praxis-induced seizures of atypical prolonged absences in a German family and episodic ataxia in a French Canadian family. ${ }^{22}$ A suggestive link between a mutation in CACNA1A and human absence epilepsy occurring in combination with cerebellar ataxia was first described in a single case. ${ }^{23}$ Subsequently came the identification of a family with a combination of absence epilepsy and cerebellar ataxia. ${ }^{24}$ It is becoming clear that a subset of EA-2 patients also exhibit an epilepsy phenotype ${ }^{23-26}$ and the relevant issues with respect to mutations within CACNA1A and epilepsy were succinctly addressed. $^{27}$

In this study we identified a patient who was originally diagnosed with epilepsy and treated with valproic acid. Subsequent examination revealed that the symptoms were consistent with a diagnosis of EA-2. The patient responded positively to treatment with a combination of acetazolamide and valproic acid. Molecular genetic analysis of the CACNA1A gene was performed in order to confirm a diagnosis of EA-2.

\section{Materials AND Methods}

\section{Subject Samples}

Blood samples were obtained with informed consent from the proband, SC, her daughter, AC, and her uncle, MC, all of whom were diagnosed with EA-2. Genomic DNA was extracted from the blood samples using standard techniques. A pedigree of the family is shown (Figure 1).

\section{Single Strand Conformational Polymorphism (SSCP)}

Patient DNA was subjected to SSCP analysis as described previously. ${ }^{28}$ Published primers ${ }^{4,11,28,29}$ were used to amplify all 47 exons from the intronic sequences flanking each exon.

\section{DNA Sequencing Analysis}

Exons containing abnormally migrating conformers were

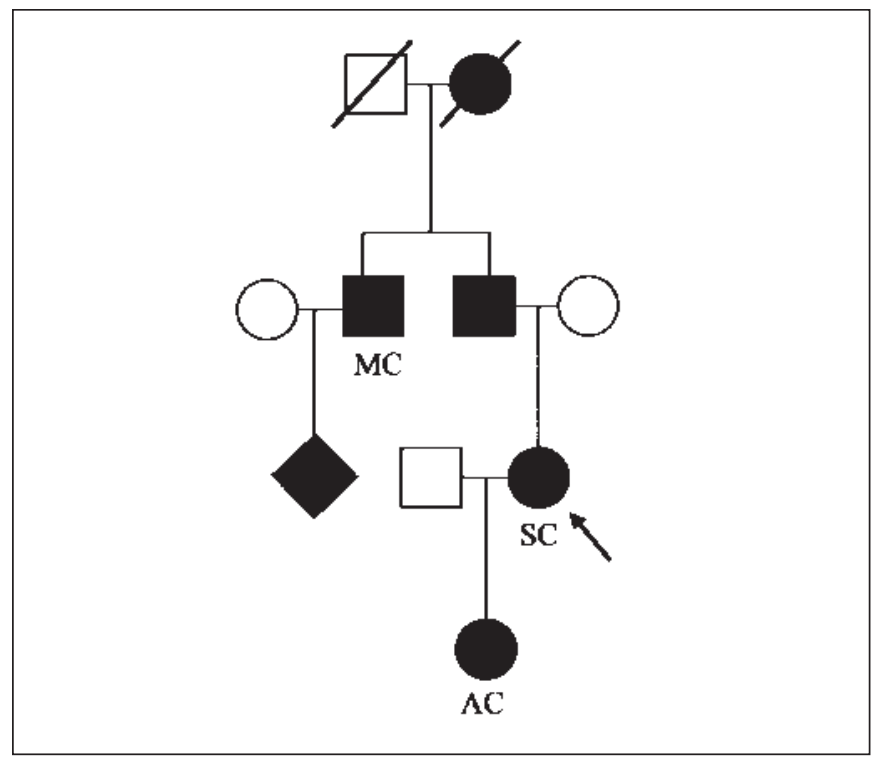

Figure 1: Pedigree of the family. The proband, SC, is indicated by an arrow. Affected individuals are represented by filled symbols. The paternal cousin of $S C$, was not seen in this study and that person is designated as affected by history. The sex of the individual is not provided as indicated by the diamond.

directly sequenced. Corresponding polymerase chain reaction (PCR) products were initially subjected to exonuclease I and shrimp alkaline phosphatase treatment at $37^{\circ} \mathrm{C}$ for $20 \mathrm{~min}$ followed by incubation at $70^{\circ} \mathrm{C}$ for ten min. The treated PCR products were then manually sequenced using the Thermo Sequenase Radiolabeled Terminator Cycle Sequencing Kit (USB Corp) according to the manufacturer's recommended conditions. Denatured sequencing reactions were immediately loaded and electrophoresed through a 6\% acrylamide gel (SequaGel-6, National Diagnostics). Gels were transferred onto filter paper, dried for two hours at $80^{\circ} \mathrm{C}$, and exposed to x-ray film (AGFA Curix Ortho HT-G Ecopac) for $18 \mathrm{~h}$ at $-80^{\circ} \mathrm{C}$. Autoradiographs were examined for sequence changes. All nucleotide, codon, and exon, numbering corresponds to GenBank accession number X99897 (http://www.ncbi.nlm.nih.gov/).

\section{Allele-Specific Oligonucleotide Hybridization (ASOH)}

Allele-Specific Oligonucleotide Hybridization (ASOH) was performed to rule out the possibility that the disease causing mutation was a polymorphism and was performed as described previously. ${ }^{28}$ Essentially, exon 12 was amplified from $200 \mathrm{ng}$ of genomic DNA from the proband and 100 normal controls. The PCR products were electrophoresed through a $1.5 \%$ agarose gel and transferred onto a Hybond-N membrane (Amersham Pharmacia Biotech) for three hours under denaturing conditions (0.5 N NaOH, 1.5 M NaCl). The blot was then neutralized (1 M Tris- $\mathrm{Cl} \mathrm{pH} 7.5,1.5 \mathrm{M} \mathrm{NaCl})$ and the DNA was UV cross-linked to the membrane. The membrane was prehybridized (5 x SSPE, 5 x Denhardt's, and $1 \%$ sodium dodecyl sulphate (SDS)) for 30 min and then probed for one hour either with wild type exon 12 allele specific oligonucleotide (ASO) (5'CTTTATGTCCGAAATGTTT-3') at $50^{\circ} \mathrm{C}$ or mutant exon 12 
ASO (5'-CTTTATGTCCAAAATGTTT-3') at $48^{\circ} \mathrm{C}$. Oligonucleotides were end-labeled using $\mathrm{T} 4$ poly-nucleotide kinase (New England Biolabs) and $\left[\gamma^{32} \mathrm{P}\right]$-ATP. Unincorporated phosphates were removed with a G-25 Sephadex spin column (Boehringer Mannheim) as per the manufacturer's instructions. The activity of the probes was determined by scintillation counting and 0.6-0.8 $\times 10^{6} \mathrm{cpm}$ of denatured probe was added per $\mathrm{mL}$ of hybridization solution. The membrane was washed twice with $2 \times$ SSPE / $0.1 \%$ SDS for $15 \mathrm{~min}$ at the hybridization temperature and then exposed to x-ray film. The mutant ASO was removed from the blot before the membrane was reprobed with the wild type ASO by washing twice in $0.1 \times$ SSPE / $0.1 \%$ SDS for $15 \mathrm{~min}$ at $70^{\circ} \mathrm{C}$.

\section{RESULTS}

\section{Clinical Description}

The proband, SC, is a 27 -year-old woman who began having spells at age 12. These lasted about 20 minutes, were sometimes preceded by a headache and were sometimes precipitated by stress. She described "dizziness", which was "light headedness," as if she might fall, but she never lost consciousness. She required special education and completed tenth grade. Her neurological examination was normal aside from dull intellectual function, depression, and mild gaze evoked nystagmus. She had been treated with valproic acid since childhood for a misdiagnosis of seizures and reported a marked reduction in the frequency of spells. Her electroencephalogram (EEG) had last been obtained at age 12, interpreted as showing "paroxysms of slow and notched slow wave activity appearing anteriorly and in general distribution...with moderate disorganization of the background." No brain imaging studies were obtained. She also suffered headaches, similar to her mother's, with pounding severe discomfort, associated with nausea, photophobia and sonophobia, but no visual or focal neurological symptoms. Medical treatment discontinued when she stopped seeing her doctor. At age 27 a diagnosis of EA-2 was made and acetazolamide $250 \mathrm{mg}$ three times daily was prescribed, resulting in a dramatic improvement that was short lived. Within one month she returned, reporting daily spells. Valproic acid $250 \mathrm{mg}$ three times daily was added and the frequency of spells was reduced to two in four months. The proband's father, paternal uncle, MC, one paternal cousin and her paternal grandmother had similar spells.

The proband's paternal uncle, MC, was initially evaluated, diagnosed, and treated in his early 30's and was re-evaluated at age 40 . He reported spells beginning at age 15 with "wobbliness and clumsiness," incoordination and slurred speech. He reported that the experience was similar to "being intoxicated." The episodes lasted minutes to hours and anxiety increased the likelihood of an attack. The frequency of attacks were significantly reduced by acetazolamide, $500 \mathrm{mg}$ twice daily, but still occasionally occurred. His neurological exam was normal except for rotary nystagmus on horizontal gaze and inability to tandem gait. A brain MRI obtained about 15 years into the illness was thought to be normal.

The proband's daughter, AC, had her first spell at age eight. The episode began with a headache, then a period lasting a minute or two of being awake but unresponsive, then clumsiness lasting several hours. The headaches were similar to those of her mother, described above. A diagnosis of epilepsy was suspected by the pediatrician. Three EEG's were obtained: one of which was normal, one showing mild slowing on the right of uncertain significance; and one showing bilateral spike wave, and polyspike slow wave discharges, with focal onset in the left frontal area and rapid bilateral synchrony. Carbamazepine was introduced and the spells were not improved. Her mother reported that the spells she witnessed, which occurred several times each week, were identical to her own. The neurological examination, performed by JHF, was completely normal. Acetazolamide $62.5 \mathrm{mg}$ bid (the patient weighed $67 \mathrm{lbs}$ ) abolished the spells over the last three months.

\section{Mutation Detection}

The DNA of SC was examined for a mutation in the CACNA1A gene. The SSCP analysis revealed a unique conformer in exon 12 (Figure 2A, lane 2) which was not detected among 100 patient and 100 control samples. The conformer was

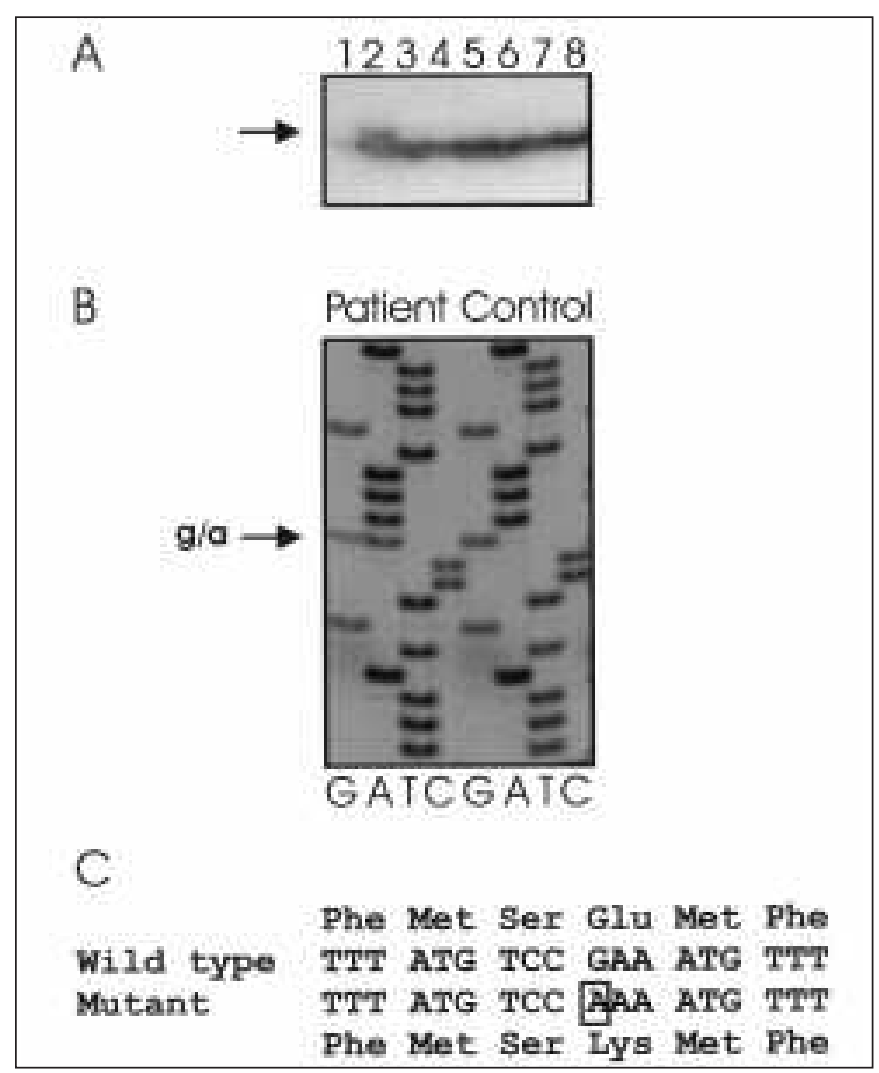

Figure 2: The aberrantly migrating conformer in a family with EA-2 was due to a $G$ to A transition in the CACNA1A gene. A) SSCP analysis of exon 12 of the CACNA1A gene showing an aberrantly migrating conformer (arrow) in the proband of a family with EA-2 (lane 2). B) DNA sequence analysis of the coding strand of exon 12 of the CACNA1A gene displays a guanine to adenosine transition at nucleotide 1872 in one allele (arrow) of the proband. DNA sequence from the autoradiograph is given in the forward orientation starting at nucleotide 1863. C) Nucleotide and amino acid comparison of wild type and mutant sequences as a result of the $G$ to A transition at position 1872. The G to A transition is boxed with the subsequent amino acid change is illustrated. 
further evaluated by PCR and direct sequencing. Sequence analysis identified a guanine to adenine transition at nucleotide position 1872 (codon 533) in one allele (Figure 2B). This transition results in the substitution of a highly conserved glutamic acid residue for a lysine amino acid in domain II S2 of the $\alpha_{1 \mathrm{~A}}$ subunit of the P/Q-type calcium channel (Figure 2C, Figure 3). CACNA1A exon 12 from the proband's daughter and uncle were subsequently sequenced and confirmed to have the same $\mathrm{G}$ to A transition at nucleotide 1872 (data not shown). An ASOH was then performed using PCR amplified DNA from the patient and an additional 100 unrelated normal controls. The mutant oligonucleotide hybridized with only the patient sample (data not shown). The nucleotide change was not listed in the single nucleotide polymorphism (SNP) database (http://www.ncbi.nlm.nih.gov/projects/SNP/).

\section{Discussion}

In the present study, we report the identification of a novel missense mutation responsible for EA-2. This guanine to adenine transition results in the substitution of a highly conserved, negatively charged glutamic acid for a positively charged lysine amino acid in the $\alpha_{1 \mathrm{~A}}$ subunit of the P/Q-type calcium channel. The intense selective pressure on the ion channel genes in general is illustrated by the high degree of sequence conservation across species ranging from humans to flies (Figure 3). The complete lack of variation at amino acid 533 is indicative of importance of this residue in either maintaining channel structure or function. The mutation was not observed among 300 controls (600 chromosomes), comprised of 200 normal and 100 patients under investigation for neurological disorders. Interestingly, the proband's condition is responsive to valproic acid, which is usually used in the treatment of absence epilepsy and has not been implicated in the treatment of EA-2. At least two mutations in the mouse CACNA1A gene have been demonstrated to cause symptoms similar to that of human absence epilepsy. Tottering mutant mice have a recessive missense mutation, Pro647Leu, in the CACNA1A gene that causes epilepsy. ${ }^{19}$ Leaner mutant mice have a splice site mutation at the 3 ' end of the CACNA1A gene that results in chronic ataxia associated with Purkinje and granule cell loss within the anterior cerebellum. ${ }^{19}$ Also,
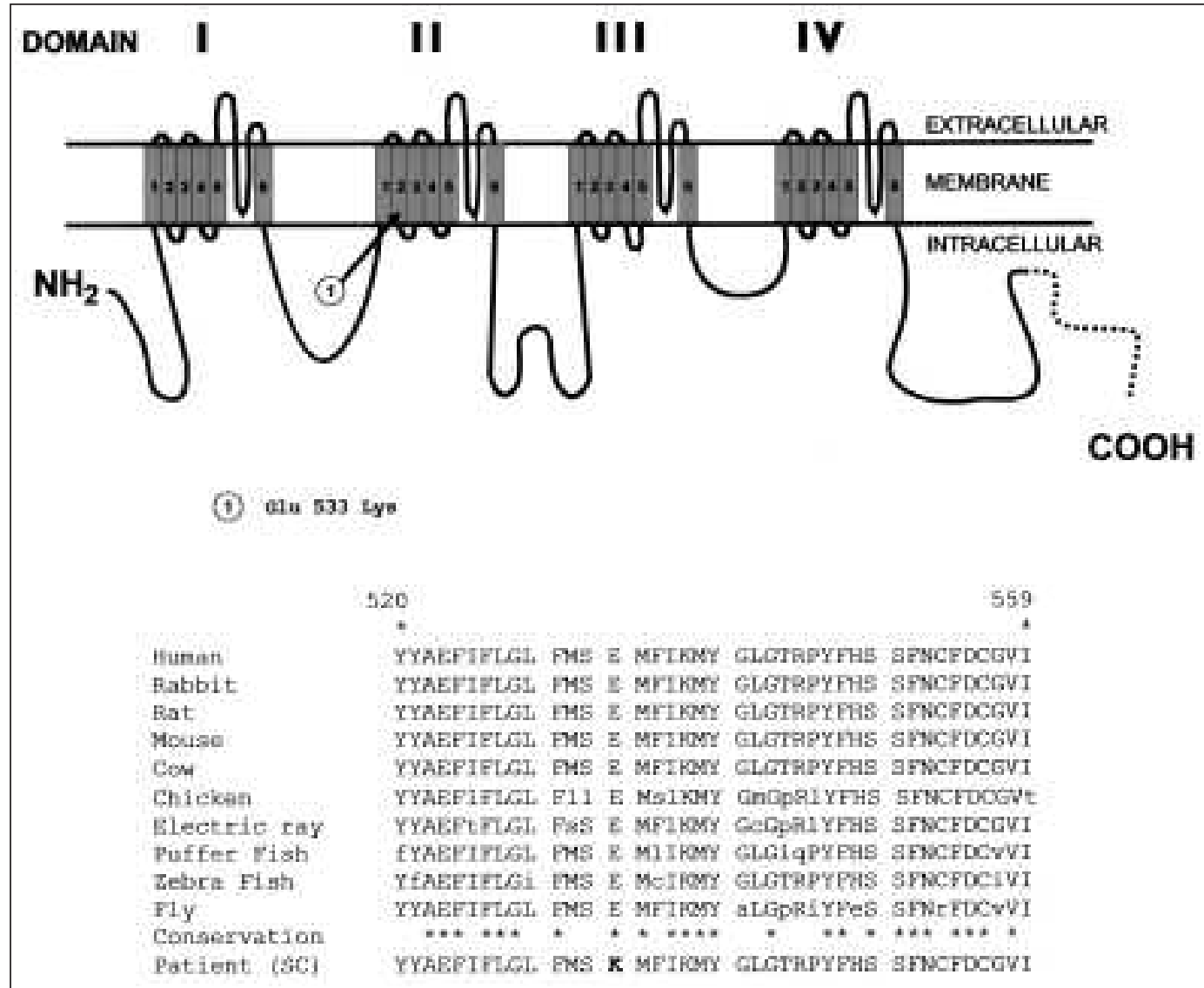

Figure 3: Glutamic acid residue at codon 533 is conserved through evolution.

(Upper) Schematic of the $P / Q$-type calcium $\alpha$ A subunit channel showing the position of the mutation. (Lower) $P / Q$ type calcium channel amino acids 520 to 559 from different species are shown. Positions of complete amino acid conservation are illustrated by an asterisk. The highly conserved glutamic acid residue is illustrated and the lysine mutation of the proband, $S C$, is in bold. 
mutations in some of the auxiliary calcium channel subunits in mice have been identified to cause symptoms of epilepsy. ${ }^{20,21}$ Mutation of the calcium channel $\gamma$ subunit with the insertion of an Etn retrotransposon into intron two leads to premature transcriptional termination in both mutant alleles and results in absence epilepsy in the stargazer mutant mouse. ${ }^{20}$ In humans, a premature truncation mutation of the calcium channel $\beta_{4}$ subunit causes juvenile myoclonic epilepsy, missense mutation causes generalized epilepsy with praxis-induced seizures and episodic ataxia. ${ }^{22}$ Our mutation in domain II S2 of the $\alpha_{1 \mathrm{~A}}$ subunit is near the $\beta$ subunit interaction site. We speculate that our missense mutation may affect the interaction of the $\alpha_{1 \mathrm{~A}}$ subunit with the $\beta$ subunit and therefore result in complete loss of channel function. There is a steady increase in the number of reports implicating the CACNA1A gene and epilepsy ${ }^{23-26}$ and further investigations are underway. ${ }^{27}$

There are a number of EA-2 patients for whom treatment with acetazolamide either doesn't work or for whom treatment ceases to be effective over time. For some patients, the disorder is severe enough that the absence of a treatment modality can be quite devastating. The potassium channel blocker 4aminopyridine has been reported to alleviate symptoms in three patients with EA-2. ${ }^{26}$ In this paper we now report a positive outcome in a patient treated with a combination of acetazolamide and valproic acid.

\section{ACKNowledgments}

The authors thank all of the family members for their participation in this study: Dr. Michael Pimental for providing blood samples of the proband's relatives, and Allison Grimsey, Fabin Han, and Jenna Hoyt for technical assistance. Kylie A Scoggan is a recipient of a Canadian Institutes of Health Research Fellowship Award. This research was funded by a grant from the Canadian Institutes of Health Research.

\section{REFERENCES}

1. Brandt T, Strupp M. Episodic ataxia type 1 and 2 (familial periodic ataxia/vertigo). Audiol Neurootol. 1997;2(6):373-83.

2. Bulman DE. Phenotype variation and newcomers in ion channel disorders. Hum Mol Genet. 1997;6(10):1679-85.

3. Wagner S, Lerche H, Mitrovic N, Heine R, George AL, LehmannHorn F. A novel sodium channel mutation causing a hyperkalemic paralytic and paramyotonic syndrome with variable clinical expressivity. Neurology. 1997;49(4):1018-25.

4. Ophoff RA, Terwindt GM, Vergouwe MN, van Eijk R, Oefner PJ, Hoffman SM, et al. Familial hemiplegic migraine and episodic ataxia type- 2 are caused by mutations in the $\mathrm{Ca} 2+$ channel gene CACNL1A4. Cell. 1996;87(3):543-52.

5. Guida S, Trettel F, Pagnutti S, Mantuano E, Tottene A, Veneziano L, et al. Complete loss of $\mathrm{P} / \mathrm{Q}$ calcium channel activity caused by a CACNA1A missense mutation carried by patients with episodic ataxia type 2. Am J Hum Genet. 2001;68(3):759-64.

6. Denier C, Ducros A, Vahedi K, Joutel A, Thierry P, Ritz A, et al. High prevalence of CACNA1A truncations and broader clinical spectrum in episodic ataxia type 2. Neurology. 1999;52(9):1816-21.

7. Friend KL, Crimmins D, Phan TG, Sue CM, Colley A, Fung VS, et al. Detection of a novel missense mutation and second recurrent mutation in the CACNA1A gene in individuals with EA-2 and FHM. Hum Genet. 1999;105(3):261-5.

8. Mantuano E, Veneziano L, Spadaro M, Giunti P, Guida S, Leggio $\mathrm{MG}$, et al. Clusters of non-truncating mutations of P/Q type Ca2+ channel subunit $\mathrm{Ca}(\mathrm{v}) 2.1$ causing episodic ataxia 2. J Med Genet. 2004;41(6):e82.
9. Spacey SD, Hildebrand ME, Materek LA, Bird TD, Snutch TP. Functional implications of a novel EA2 mutation in the P/Q-type calcium channel. Ann Neurol. 2004;56(2):213-20.

10. Jodice C, Mantuano E, Veneziano L, Trettel F, Sabbadini G, Calandriello L, et al. Episodic ataxia type 2 (EA2) and spinocerebellar ataxia type 6 (SCA6) due to CAG repeat expansion in the CACNA1A gene on chromosome 19p. Hum Mol Genet. 1997;6(11):1973-8.

11. Yue Q, Jen JC, Nelson SF, Baloh RW. Progressive ataxia due to a missense mutation in a calcium-channel gene. Am J Hum Genet. 1997;61(5):1078-87.

12. Gillard SE, Volsen SG, Smith W, Beattie RE, Bleakman D, Lodge D. Identification of pore-forming subunit of P-type calcium channels: an antisense study on rat cerebellar Purkinje cells in culture. Neuropharmacology. 1997;36(3):405-9.

13. Pinto A, Gillard S, Moss F, Whyte K, Brust P, Williams M, et al. Human autoantibodies specific for the alpha1A calcium channel subunit reduce both P-type and Q-type calcium currents in cerebellar neurons. Proc Natl Acad Sci USA. 1998;95(14):832833.

14. Catterall WA. Structure and function of neuronal $\mathrm{Ca} 2+$ channels and their role in neurotransmitter release. Cell Calcium. 1998;24(56):307-23.

15. Mori Y, Friedrich T, Kim MS, Mikami A, Nakai J, Ruth P, et al. Primary structure and functional expression from complementary DNA of a brain calcium channel. Nature. 1991;350(6317):398402.

16. Starr TV, Prystay W, Snutch TP. Primary structure of a calcium channel that is highly expressed in the rat cerebellum. Proc Natl Acad Sci USA. 1991;88(13):5621-5.

17. Westenbroek RE, Sakurai T, Elliott EM, Hell JW, Starr TV, Snutch $\mathrm{TP}$, et al. Immunochemical identification and subcellular distribution of the alpha 1A subunits of brain calcium channels. $\mathbf{J}$ Neurosci. 1995;15(10):6403-18.

18. Catterall WA. Structure and function of voltage-gated ion channels. Annu Rev Biochem. 1995;64:493-531.

19. Fletcher CF, Lutz CM, O'Sullivan TN, Shaughnessy JD, Jr., Hawkes $\mathrm{R}$, Frankel WN, et al. Absence epilepsy in tottering mutant mice is associated with calcium channel defects. Cell. 1996;87(4):607-17.

20. Letts VA, Felix R, Biddlecome GH, Arikkath J, Mahaffey CL, Valenzuela $\mathrm{A}$, et al. The mouse stargazer gene encodes a neuronal Ca2+-channel gamma subunit. Nat Genet. 1998;19(4):340-7.

21. Burgess DL, Jones JM, Meisler MH, Noebels JL. Mutation of the $\mathrm{Ca} 2+$ channel beta subunit gene $\mathrm{Cchb} 4$ is associated with ataxia and seizures in the lethargic (lh) mouse. Cell. 1997;88(3):385-92.

22. Escayg A, De Waard M, Lee DD, Bichet D, Wolf P, Mayer T, et al. Coding and noncoding variation of the human calcium-channel beta4-subunit gene CACNB4 in patients with idiopathic generalized epilepsy and episodic ataxia. Am J Hum Genet. 2000;66(5):1531-9.

23. Jouvenceau A, Eunson LH, Spauschus A, Ramesh V, Zuberi SM, Kullmann DM, et al. Human epilepsy associated with dysfunction of the brain P/Q-type calcium channel. Lancet. 2001;358(9284):801-7.

24. Imbrici P, Jaffe SL, Eunson LH, Davies NP, Herd C, Robertson R, et al. Dysfunction of the brain calcium channel CaV2.1 in absence epilepsy and episodic ataxia. Brain. 2004;127(12):2682-92.

25. Jen J, Kim GW, Baloh RW. Clinical spectrum of episodic ataxia type 2. Neurology. 2004;62(1):17-22.

26. Strupp M, Kalla R, Dichgans M, Freilinger T, Glasauer S, Brandt T. Treatment of episodic ataxia type 2 with the potassium channel blocker 4-aminopyridine. Neurology. 2004;62(9):1623-5.

27. Hanna MG, Graves TD, Jaffe S, Imbrici P, Kullmann DM, on behalf of the authors. Dysfunction of the brain calcium channel CaV2.1 in absence epilepsy and episodic ataxia-authors' response. Brain. 2005;128(6):E33

28. Scoggan KA, Chandra T, Nelson R, Hahn AF, Bulman DE. Identification of two novel mutations in the CACNA1A gene responsible for episodic ataxia type 2. J Med Genet. 2001;38(4):249-53.

29. Trettel F, Mantuano E, Calabresi V, Veneziano L, Olsen AS, Georgescu A, et al. A fine physical map of the CACNA1A gene region on 19p13.1-p13.2 chromosome. Gene. 2000;241(1):45-50. 